American Journal of Agricultural and Biological Sciences 6 (3): 339-347, 2011

ISSN 1557-4989

(C) 2011 Science Publications

\title{
Nutritional Status and Obesity among Adults of Amman and Al-Balq'a Governorates
}

\author{
Basem F. Dababneh, Jafar M. El-Qudah and Alaa A. Al-Bakheit \\ Department of Nutrition and Food Processing, \\ Faculty of Agricultural Technology, \\ Al-Balq'a Applied University, Al-Salt 19117, Jordan
}

\begin{abstract}
Problem statement: Obesity is a critical health problem worldwide and it is a serious prevalent disorder. The objective of this investigation was to assess the food consumption pattern and the prevalence of obesity of adult sample in Amman and Al-Balq'a governorates-Jordan. Approach: The study was performed on random sample of 544 apparently healthy adult volunteers consisted of men and women between the ages of 18 and 70 years. A cross-sectional dietary survey based on questionnaire model was carried out. Data on personal, food consumption, indicators of socio-economic level, measurements of weight and height were collected. The dietary habits were assessed by means of a Food-Frequency Questionnaire (FFQ) and Body Mass Index (BMI) was used for the assessment of an overweight and obesity. Results: Based on BMI classification, the prevalence of overweight was more common among males compared to females $36.2 \%$ and $24.4 \%$ respectively in Amman governorate and 37.5 and $23.7 \%$ in Al-Balq'a governorate, while the prevalence of obesity was higher among females compared to males 21.5 and $13.8 \%$, respectively in Amman and $20.7 \%$ and $14.0 \%$ in Al-Balq'a. The current study showed that $48.0 \%$ of the whole sample was either overweight or obese. Considerable variations were found among individuals for the amounts of food consumed. Generally, males from both governorates consume more quantities from most food items than females. The mean intake of the total sample in Amman and Al-Balq'a of meat and poultry products in $\mathrm{g}$ day was 119 and 132, eggs 31.9 and 36.1, milk 131.5 and 167.4, dairy products 169.8 and 188.6, cereal and cereal based products 549.1 and 696.7, vegetables 395.9 and 405.2 and fruits 277 and 252, respectively. Low consumption of fish was reported, $14.2 \mathrm{~g} \mathrm{day}^{-1}$ in Amman and $13.8 \mathrm{~g}$ d in Al-Balq'a. Fats and oils and sugar were highly consumed, 34.7 and 100.2 in Amman and 80.9 and 47.7 in AlBalq'a, respectively. Conclusion: The prevalence of overweight and obesity among males and females is high. These findings should be considered in the Jordanian national nutrition health promotion program as an attempt for effective prevention of CVD and related co-morbidities.
\end{abstract}

Key words: Nutritional status, Body Mass Index (BMI), Food-Frequency Questionnaire (FFQ), effective prevention, individual dietary, non-communicable diseases, food consumption, sample characteristics, world health organization, nutritional disorders

\section{NTRODUCTION}

Obesity prevails in various communities of the world. Its prevalence is escalating at an alarming rate to epidemic proportions throughout the developed world. Furthermore, obesity is no longer just a concern for developed countries, but is also becoming an increasing problem in many developing countries. Overweight and obesity are major public health problems and the most common nutritional disorders (WHO, 2003; Jahangeer et al., 2010). Both overall and abdominal obesity are associated with non communicable chronic diseases such as type 2 diabetes, cardiovascular and cerebrovascular diseases, digestive disorders and cancer (Manson, 1995; Shahwan-Akl, 2010). Furthermore, obesity is a major independent risk factor for the development of hypertension, type 2 diabetes and dyslipidemia (Jia, et al., 2002).

Body Mass Index (BMI), a measure of weight adjusted for height is often used as an indicator of overall adiposity. BMI is influenced by genes, diet and other aspects of lifestyle such as alcohol consumption, smoking habits, physical activity and other

Corresponding Author: Basem F. Dababneh, Department of Nutrition and Food Processing, Al-Balq'a Applied University, Faculty of Agricultural Technology, Al-Salt 19117, Jordan Tel: +962(5) 3491111 Fax: +962(5) 3530469 
sociodemographic factors such as educational level or marital status (Molarius et al., 2000; Fang and Lee, 2009). Surveys of food intake by individuals can be conducted by five main methods: $24 \mathrm{~h}$ dietary recalls, food records, duplicate diet portion, dietary history and Food-Frequency Questionnaires (FFQs) (Kroes et al., 2002; Jahangeer et al., 2010). The importance of individual dietary surveys resides in identifying the association between an individual's dietary pattern over a period of time and the associated phenomena that can result from that particular dietary behavior.

According to WHO report, there are more than 250 million obese adults and about 1.1 billion overweight people worldwide (WHO, 1998). Environmental and behavioral changes brought about by economic development, modernization and urbanization has been linked to the rise in global obesity. The variation in prevalence of obesity epidemic in various races and community of the world may be attributed to heredity, age, sex, diet, eating patterns, life style and/or behavior (Epstein and Higgins, 1992; Gurney and Gorstein, 1988). There are indications that obesity and other noncommunicable diseases have increased in many Middle Eastern countries (Musaiger and Miladi, 1996; Ahmadi et al., 2010). A few population studies from the area have indicated that the prevalence of obesity is higher than in most other countries of the world (Al-Nuaim et al., 1996; Musaiger and Miladi, 1996; Jaddou et al., 1998b; CDC, 2006).

Recent studies conducted in Jordan showed high prevalence of diabetes mellitus, hypertension and dyslipidemia (Ajlouni et al., 1998b; Jaddou et al., 1996). There are also few studies which indicate an alarming high prevalence rate of obesity among adult women and men (Ahmad et al., 2006; Takruri, 2003). In the present study, an individual dietary intake survey was conducted to investigate, measure and assess the food consumption pattern of the adult population living in Amman and Al-Balqa and to identify inadequate or excessive intake of specific food groups particularly linked to non-communicable diseases.

\section{MATERIALS AND METHODS}

Sample characteristics: Across-sectional dietary survey was carried out in a random sample of the adult population living in Amman and Al-Balq'a governorates. Our sample consisted of 544 apparently healthy men and women between the ages of 18 and 70 years. Of these 273 were from Amman governorate (138 males and 135 females) and 271 were from AlBalq'a governorate (136 males and 135 females). Data were collected by trained researchers from Al-Balq'a Applied University during March-June 2008. Approval to implement the study protocol was obtained from the committee of scientific research of Al-Balq'a Applied University.

Food consumption and dietary assessment method: Food consumption data were obtained using a questionnaire which included, in addition to personal data and indicators of socio-economic level (education, occupation, family and household information), measurements of weight $(\mathrm{kg})$ and height $(\mathrm{cm})$ and use of dietary supplements. Dietary habits were assessed by means of a Food-Frequency Questionnaire (FFQ), which was designed to estimate food intake over the past year. It consisted of a list of food items as normally consumed. A reference portion, expressed in household measures or grams, was specified for each food item in the FFQ. The individual was asked to estimate the number of times per day, week, month or year he/she consumed this particular food product and the amount usually eaten per food item by making comparisons with the specified reference portion. Common household measures, measuring cups, spoons and a ruler were shown to assist the individual in the estimation process.

Assessment of obesity and overweight: Self-reported weight and height data were used. BMI was calculated as weight $(\mathrm{kg})$ height $^{2}\left(\mathrm{~m}^{2}\right)$ and it was used for the assessment of overweight and obesity. The method used for the classification of obesity and overweight was according to the proposed cutoff points for BMI by the World Health Organization (WHO, 1999), based on this criteria the cutoff points for overweight and obesity were defined as (BMI of 25 and $30 \mathrm{~kg} \mathrm{~m}^{2}$, respectively).

Data analysis: Food Composition Tables for use in the Middle East (Pellett, 1970) and USDA food data base (USDA, 2007) were used to convert intakes of food into nutrients. The devised analysis module permitted to group food items into categories and to determine mean consumption values per food item and per food group ( $g$, day), average daily intake per individual, per sex group (g, day) and per age group (g, day) and the percentage of consumers per food item and per food group. Composite dishes were analyzed as normally consumed, i.e. without extracting added oil, fat or other ingredients from the recipes.

Statistical analysis: All subsequent statistical analyses were performed using the paired student's t-test method to compare the group means. The analyses were conducted stratified by age and gender whenever appropriate. A P-value $<0.05$ or $<0.05$ was considered significant. 
Am. J. Agri. \& Biol. Sci., 6 (3): 339-347, 2011

Table 1: Description of Adults sample from Amman and Al-Balq'a governorates

\begin{tabular}{|c|c|c|c|c|c|c|c|c|c|c|c|c|}
\hline \multirow[b]{3}{*}{ Personal information } & \multicolumn{4}{|c|}{ Amman } & \multicolumn{4}{|c|}{ Al-Balq'a } & \multirow{2}{*}{\multicolumn{2}{|c|}{$\begin{array}{l}\text { Amman } \\
\text { Total } \\
\mathrm{n}=273\end{array}$}} & \multirow{2}{*}{\multicolumn{2}{|c|}{$\begin{array}{l}\text { Al-Balq'a } \\
\text { Total } \\
\mathrm{n}=271\end{array}$}} \\
\hline & \multicolumn{2}{|c|}{$\begin{array}{l}\text { Males } \\
\mathrm{n}=138\end{array}$} & \multicolumn{2}{|c|}{$\begin{array}{l}\text { Females } \\
\mathrm{n}=135\end{array}$} & \multicolumn{2}{|c|}{$\begin{array}{l}\text { Males } \\
\mathrm{n}=136\end{array}$} & \multicolumn{2}{|c|}{$\begin{array}{l}\text { Females } \\
\mathrm{n}=135\end{array}$} & & & & \\
\hline & No. & $(\%)$ & No. & $(\%)$ & No. & $(\%)$ & No. & $(\%)$ & No. & $(\%)$ & No. & $(\%)$ \\
\hline \multicolumn{13}{|l|}{ Marital status } \\
\hline Single & 64 & 46.4 & 65 & 48.1 & 71 & 52.2 & 74 & 54.8 & 129 & 47.3 & 145 & 53.5 \\
\hline Married & 74 & 53.6 & 64 & 47.4 & 63 & 46.3 & 56 & 41.5 & 138 & 50.5 & 119 & 43.9 \\
\hline Widower & 0 & 0 & 6 & 4.4 & 1 & 0.7 & 4 & 3.0 & 6 & 2.2 & 5 & 1.8 \\
\hline Divorced & 0 & 0 & 0 & 0 & 1 & 0.7 & 1 & 0.7 & 0 & 0 & 2 & 0.7 \\
\hline \multicolumn{13}{|l|}{ Educational level } \\
\hline University & 99 & 71.7 & 98 & 72.6 & 93 & 68.4 & 96 & 71.1 & 197 & 72.2 & 189 & 69.7 \\
\hline High School & 36 & 26.1 & 35 & 25.9 & 41 & 30.1 & 31 & 23.0 & 71 & 26.0 & 72 & 26.6 \\
\hline Illiterate & 3 & 2.2 & 2 & 1.5 & 2 & 1.5 & 8 & 5.9 & 5 & 1.8 & 10 & 3.7 \\
\hline \multicolumn{13}{|l|}{ Occupation } \\
\hline Student & 30 & 21.7 & 39 & 28.9 & 35 & 25.7 & 60 & 44.4 & 69 & 25.3 & 95 & 35.1 \\
\hline Public sector employee & 37 & 26.8 & 14 & 10.4 & 39 & 28.7 & 24 & 17.8 & 51 & 18.7 & 63 & 13.3 \\
\hline Private sector employee & 61 & 44.2 & 20 & 14.8 & 50 & 36.8 & 17 & 12.6 & 81 & 29.7 & 67 & 24.7 \\
\hline Don't work & 10 & 7.2 & 62 & 45.9 & 12 & 8.8 & 34 & 25.2 & 72 & 26.4 & 46 & 17.0 \\
\hline \multicolumn{13}{|l|}{ Income level } \\
\hline \multicolumn{13}{|l|}{ Low } \\
\hline$(<250 \mathrm{JD})$ & 7 & 5.1 & 6 & 4.4 & 9 & 6.6 & 28 & 20.7 & 13 & 4.8 & 37 & 13.7 \\
\hline \multicolumn{13}{|l|}{ Moderate } \\
\hline (250-500JD) & 54 & 39.1 & 48 & 35.6 & 65 & 47.8 & 66 & 48.9 & 102 & 37.4 & 131 & 48.3 \\
\hline \multicolumn{13}{|l|}{ High } \\
\hline$(>500 \mathrm{JD})$ & 77 & 55.8 & 81 & 60.0 & 62 & 45.6 & 41 & 30.4 & 158 & 57.9 & 103 & 38.0 \\
\hline
\end{tabular}

Table 2: Body mass index classifications calculated for both males and females from amman and Al-Balq'a governorates

\begin{tabular}{|c|c|c|c|c|c|c|c|c|c|c|c|c|c|c|}
\hline \multirow[b]{3}{*}{ BMI } & \multicolumn{6}{|c|}{ Amman } & \multicolumn{8}{|c|}{ Al-Balq’a } \\
\hline & \multicolumn{2}{|c|}{$\begin{array}{l}\text { Males } \\
\mathrm{n}=138\end{array}$} & \multicolumn{2}{|c|}{$\begin{array}{l}\text { Females } \\
\mathrm{n}=135\end{array}$} & \multicolumn{2}{|c|}{$\begin{array}{l}\text { Total } \\
\mathrm{n}=273\end{array}$} & \multicolumn{2}{|c|}{$\begin{array}{l}\text { Males } \\
\mathrm{n}=136\end{array}$} & \multicolumn{2}{|c|}{$\begin{array}{l}\text { Females } \\
\mathrm{n}=135\end{array}$} & \multicolumn{2}{|c|}{$\begin{array}{l}\text { Total } \\
\mathrm{n}=271\end{array}$} & \multicolumn{2}{|c|}{$\begin{array}{l}\text { Total } \\
\mathrm{n}=544\end{array}$} \\
\hline & No. & $(\%)$ & No. & $(\%)$ & No. & $(\%)$ & No. & $(\%)$ & No. & $(\%)$ & No. & $(\%)$ & No. & $(\%)$ \\
\hline Under weight $(<18.5)$ & 2 & 1.4 & 7 & 5.2 & 9 & 3.3 & 1 & 0.7 & 12 & 8.9 & 13 & 4.8 & 22 & 4.0 \\
\hline Normal (18.5-24.9) & 67 & 48.6 & 66 & 48.9 & 133 & 48.7 & 65 & 47.8 & 63 & 46.7 & 128 & 47.2 & 261 & 48.0 \\
\hline Over weight (25-29.9) & 50 & 36.2 & 33 & 24.4 & 83 & 30.4 & 51 & 37.5 & 32 & 23.7 & 83 & 30.6 & 166 & 30.5 \\
\hline Obese $(\geq 30)$ & 19 & 13.8 & 29 & 21.5 & 48 & 17.6 & 19 & 14.0 & 28 & 20.7 & 47 & 17.3 & 95 & 17.5 \\
\hline
\end{tabular}

Table 3: The average intake in grams of food groups based on Food Frequency Questionnaire (FFQ) of males and females from Amman and Al-Balq'a governorates

\begin{tabular}{|c|c|c|c|c|c|c|c|c|}
\hline \multirow[b]{2}{*}{ Food group } & \multicolumn{2}{|l|}{ Amman } & \multicolumn{2}{|l|}{ Al-Balq'a } & \multirow[b]{2}{*}{$\begin{array}{l}\text { Total males } \\
\mathrm{n}=274\end{array}$} & \multirow[b]{2}{*}{$\begin{array}{l}\text { Total females } \\
\mathrm{n}=270\end{array}$} & \multirow{2}{*}{$\begin{array}{l}\text { Amman } \\
\text { Total } \\
\mathrm{n}=273\end{array}$} & \multirow{2}{*}{$\begin{array}{l}\text { Al-Balq'a } \\
\text { Total } \\
\mathrm{n}=271\end{array}$} \\
\hline & $\begin{array}{l}\text { Males } \\
\mathrm{n}=138\end{array}$ & $\begin{array}{l}\text { Females } \\
\mathrm{n}=135\end{array}$ & $\begin{array}{l}\text { Males } \\
\mathrm{n}=136\end{array}$ & $\begin{array}{l}\text { Females } \\
\mathrm{n}=135\end{array}$ & & & & \\
\hline Milk and dairy product & 335.2 & 267.0 & 427.0 & 284.7 & 381.1 & 275.9 & 301.1 & 355.9 \\
\hline Meat and beans & $341.4^{* *}$ & 221.5 & $389.0^{* *}$ & 217.6 & $365.2^{* *}$ & 219.6 & 281.5 & 303.3 \\
\hline Vegetables & $502.9^{* *}$ & 470.9 & $574.1^{*}$ & 446.0 & $538.5^{* *}$ & 458.5 & 486.9 & 510.1 \\
\hline Fruit & 273.1 & $280.7^{*}$ & 284.3 & 219.4 & $278.7^{* *}$ & 250.1 & 276.9 & 251.9 \\
\hline Fat and sweets & 127.6 & 208.4 & 206.6 & 111.9 & 167.1 & 160.2 & 168.0 & 159.3 \\
\hline Drinks and beverages & $959.0^{*}$ & 777.9 & $1103.7^{*}$ & 940.2 & $1031.4^{*}$ & 859.1 & 868.4 & 1220.0 \\
\hline
\end{tabular}

$* \mathrm{P}<0.05, * * \mathrm{P}<0.01$

\section{RESULTS}

The sample consisted of 544 participants. Among them 273 (138 $\mathrm{M}$ and $135 \mathrm{~F}$ ) were from Amman and 271 (136 $\mathrm{M}$ and $135 \mathrm{~F}$ ) were from Al-Balq'a. $44.4 \%$ of females from Al-Balq'a were students, while only
28.9\% from Amman were students. The sample characteristics are presented in Table 1.

Body Mass Index Classifications were calculated for both males and females from Amman and Al-Balq'a governorates (Table 2). The results show that there were no significant differences between males and 
females of Amman and Al-Balq'a in BMI. The data indicated that percentages of females living in Amman with underweight (BMI $<18.5 \mathrm{~kg} \mathrm{~m} 2)$ and normal weight (BMI 18.5-24.9 $\mathrm{kg} \mathrm{m} 2$ ) categories of BMI were 5.2 and $48.9 \%$ respectively. On the other hand, percentages of the male subjects with overweight (BMI 25.0-29.9 kg m2) category of BMI in Amman and AlBalq'a were 36.2 and $37.5 \%$ respectively. Considering $\mathrm{BMI} \geq 30$ as obese, the percentage was $17.6 \%$ among the study sample in Amman and $17.3 \%$ in Al-Balq'a. Thus, the prevalence of overweight and obesity (BMI) in the study sample was $48.0 \%$.

Table 3 shows the average intake in grams of food groups based on Food Frequency Questionnaire (FFQ) of males and females from Amman and Al-Balq'a governorates, with gender differences between them. There were also differences in the total sample between both governorates with respect to the average intake of meat and beans, vegetables and fruits $(\mathrm{p}<0.01)$ and drinks and beverages $(p<0.05)$. Table 4 shows the daily average intake in grams of some food items based on Food Frequency Questionnaire (FFQ) of males and females from Amman and Al-Balq'a governorates. As can be seen from this table, the mean daily food consumption of the subjects of many food items were frequently consumed by both sexes in Amman and AlBalq'a; however, considerable variations were found among individuals for the amounts of food consumed. Generally, males from both governorates consume more quantities from most food items than females. The daily average intake of males from Amman governorate is generally higher than females in all food items except skim milk, White cheese, lentils, walnut, Cauliflower, potato, tomato, Lettuce, Cabbage, Peppermint, Orange, Lemon, Peach, Jams, Sugars and Spreading butter.

\section{DISCUSSION}

The present study dealt with a group of adult males and females living in Amman and Al-Balq'a, Jordan. Several important findings were obtained from this study. Based on BMI classification, the prevalence of overweight was more common among males compared to females (36.2 and $24.4 \%$ respectively) in Amman governorate and 37.5 and $23.7 \%$ in Al-Balq'a governorate, while the prevalence of obesity was higher among females compared to males 21.5 and $13.8 \%$, respectively) in Amman and 20.7 and $14.0 \%$ in AlBalq'a. The current study showed that $48.0 \%$ of the whole sample was either overweight or obese. These results are in agreement with other studies in Jordan as well as other regional countries. Among Jordanian adults the overall prevalence of obesity was 49.7; $32.7 \%$ in males and $59.8 \%$ in females (Ajlouni et al., 1998a; DOS, 2009) indicates that, the mean BMI of women in Jordan is 26.6, higher than the normal BMI range of 18.5-24.9. Forty-one percent of women fall in the normal BMI category. Five percent of women fall below the cutoff of 18.5 , indicating that the level of chronic energy deficiency is relatively low in Jordan. However, an alarming proportion of women - more than half (54\%) - have a BMI of over 25 and thus can be considered overweight or obese. In general, very young women are more likely than other women to suffer from chronic energy deficiency. Mean BMI is higher in women in the oldest age group (45-49 years old). Older women and women with no education or elementary education are also more likely to have overweight or obese (El-Hazmi and Warsy, 2000; AlNuaim et al., 1996; Ajlouni et al., 1998a). Furthermore, the national behavioral risk factor survey in Jordan conducted in 2004 indicated increase in the prevalence of obesity among Jordanian adults to $19.5 \%$ in 2004 , a $52.3 \%$ increase from the 2002 prevalence of $12.8 \%$. In 2004, approximately $55.0 \%$ of adult respondents (52.3\% of men and $57.1 \%$ of women) were categorized as either overweight or obese (CDC, 2006).

The prevalence rate of obesity among adults of Arabian Peninsula is among the highest in the world. Musaiger et al. (2000) studied the prevalence of obesity in relation to lifestyle and social factors in Bahraini natives, aged 30-79 years. They found that prevalence of obesity was $56 \%$ and $79.6 \%$ in males and females and this higher incident was attributed to sedentary life style, dietary habits and history of diabetes and hypertension. In another survey prevalence of obesity in Al-khobar Saudi Arabia was $28.6 \%$ by BMI and $39.3 \%$ by triceps skin fold measurement in female students (Al-Abad and Al-Sowielem, 1998). Similarly, Al Isa (1995) assessed prevalence of obesity in Kuwaiti adults and reported $70.2 \%$ overweight and $36.4 \%$ obesity. Current prevalence data from individual national studies suggests that the range of obesity prevalence in European countries is from 10 to 20\% for men and $10-25 \%$ for women. Prevalence of obesity has increased by about $10-40 \%$ in the majority of European countries in the past 10 years. The most dramatic increase has been in the UK where it has more than doubled since 1980 . In UK $61 \%$ of men and $52 \%$ of women are either overweight or obese. A greater proportion of men $(45 \%)$ than women $(34 \%)$ are overweight, but a slightly lower proportion of men $(16 \%)$ than women $(17 \%)$ is obese (WHO, 1998). 
Am. J. Agri. \& Biol. Sci., 6 (3): 339-347, 2011

Table 4: The daily average intake in grams of some food items based on Food Frequency Questionnaire (FFQ) of males and females from Amman and Al-Balq'a governorates

\begin{tabular}{|c|c|c|c|c|c|c|c|c|}
\hline \multirow[b]{2}{*}{ Food Group } & \multicolumn{2}{|l|}{ Amman } & \multicolumn{2}{|c|}{ Al-Balq'a } & \multirow[b]{2}{*}{$\begin{array}{l}\text { Total Amman } \\
\mathrm{n}=273\end{array}$} & \multirow[b]{2}{*}{$\begin{array}{l}\text { Total Al-Balq'a } \\
\mathrm{n}=271\end{array}$} & \multirow[b]{2}{*}{$\begin{array}{l}\text { Total Males } \\
n=274\end{array}$} & \multirow[b]{2}{*}{$\begin{array}{l}\text { Total females } \\
\mathrm{n}=270\end{array}$} \\
\hline & $\begin{array}{l}\text { Males } \\
\mathrm{n}=138\end{array}$ & $\begin{array}{l}\text { Females } \\
\mathrm{n}=135\end{array}$ & $\begin{array}{l}\text { Males } \\
\mathrm{n}=136\end{array}$ & $\begin{array}{l}\text { Females } \\
\mathrm{n}=135\end{array}$ & & & & \\
\hline \multicolumn{9}{|c|}{ Milk and dairy product } \\
\hline Whole & 113.4 & 72 & 170.9 & 73.4 & 92.7 & 122.2 & 142.2 & 72.7 \\
\hline Low fat & 33.5 & 21.4 & 37.4 & 28.2 & 27.5 & 32.8 & 35.5 & 24.8 \\
\hline Skim & 7.9 & 14.7 & 8.6 & 16.1 & 11.3 & 12.4 & 8.3 & 15.4 \\
\hline Yoghurt & 95.7 & 85.4 & 96.7 & 102.3 & 90.6 & 99.5 & 96.2 & 93.9 \\
\hline Labneh & 39.2 & 26.7 & 54.9 & 25.5 & 33 & 40.2 & 47.1 & 26.1 \\
\hline White cheese & 27.8 & 30.4 & 32.7 & 21.4 & 29.1 & 27.1 & 30.3 & 25.9 \\
\hline Process cheese & 17.7 & 16.4 & 25.8 & 17.8 & 17.1 & 21.8 & 21.8 & 17.1 \\
\hline \multicolumn{9}{|l|}{ Meat and beans } \\
\hline Beef & 35.9 & 17.6 & 35.7 & 16.2 & 26.8 & 26 & 35.8 & 16.9 \\
\hline Sheep & 43.4 & 23.6 & 52 & 26 & 33.5 & 39 & 47.7 & 24.8 \\
\hline Chicken & 77 & 40.3 & 90.8 & 43.2 & 58.7 & 67 & 83.9 & 41.8 \\
\hline Fish & 16.7 & 11.6 & 18 & 9.6 & 14.2 & 13.8 & 17.4 & 10.6 \\
\hline Egg & 36.4 & 27.3 & 45.7 & 26.4 & 31.9 & 36.1 & 41.1 & 26.9 \\
\hline Lentils & 34.9 & 42.7 & 36.2 & 38.3 & 38.8 & 37.3 & 35.6 & 40.5 \\
\hline chick peas & 35.2 & 18.9 & 43.1 & 20.1 & 27.1 & 31.6 & 39.2 & 19.5 \\
\hline Black beans & 21.9 & 13.1 & 30.3 & 12 & 17.5 & 21.2 & 26.1 & 12.6 \\
\hline White beans & 19.8 & 13.6 & 15.7 & 15.4 & 16.7 & 15.6 & 17.8 & 14.5 \\
\hline Walnut & 2.5 & 3.5 & 3.4 & 1.9 & 3 & 2.7 & 3 & 2.7 \\
\hline Peanut & 14 & 7 & 15.1 & 6.4 & 10.5 & 10.8 & 14.6 & 6.7 \\
\hline Hazelnut & 3.7 & 2.3 & 3 & 2.1 & 3 & 2.6 & 3.4 & 2.2 \\
\hline \multicolumn{9}{|l|}{ Vegetables } \\
\hline Green beans & 22.1 & 12.4 & 28.2 & 16.2 & 17.3 & 22.2 & 25.2 & 14.3 \\
\hline Peas & 18.8 & 15.5 & 16.6 & 13.2 & 17.2 & 14.9 & 17.7 & 14.4 \\
\hline Cauliflower & 14.4 & 16.9 & 27 & 16.6 & 15.7 & 21.8 & 20.7 & 16.8 \\
\hline Squash & 43.7 & 27.2 & 44.5 & 24.3 & 35.5 & 34.4 & 44.1 & 25.8 \\
\hline Egg plant & 43.3 & 27.7 & 41.7 & 24.2 & 35.5 & 33 & 42.5 & 26 \\
\hline Potato & 86.5 & 96.3 & 104.2 & 106 & 91.4 & 105.1 & 95.4 & 101.2 \\
\hline Carrot & 51.2 & 37 & 31.4 & 36.7 & 44.1 & 34.1 & 41.3 & 36.9 \\
\hline Tomato & 112.5 & 117.1 & 164.5 & 111.2 & 114.8 & 137.9 & 138.5 & 114.2 \\
\hline Mallow & 33.4 & 20.6 & 33.3 & 23.8 & 27 & 28.6 & 33.4 & 22.2 \\
\hline Spinach & 21.8 & 20.4 & 18.4 & 8.5 & 21.1 & 13.5 & 20.1 & 14.5 \\
\hline Lettuce & 14.1 & 33.2 & 22.3 & 26.1 & 23.7 & 24.2 & 18.2 & 29.7 \\
\hline Cabbage & 25.9 & 30 & 29.2 & 25.4 & 28 & 27.3 & 27.6 & 27.7 \\
\hline Peppermint & 5 & 6.9 & 6.1 & 5.9 & 6 & 6 & 5.6 & 6.4 \\
\hline Parsley & 10.2 & 9.7 & 6.7 & 7.9 & 10 & 7.3 & 8.5 & 8.8 \\
\hline \multicolumn{9}{|l|}{ Fruit } \\
\hline Banana & 83.4 & 75.6 & 76.2 & 56.9 & 79.5 & 66.6 & 79.8 & 66.3 \\
\hline Orange & 64.7 & 65.1 & 64.8 & 53.7 & 64.9 & 59.3 & 64.8 & 59.4 \\
\hline Apple & 73.5 & 70.1 & 84.2 & 42.3 & 71.8 & 63.3 & 78.9 & 56.2 \\
\hline Lemon & 35.4 & 45.9 & 40.4 & 48.4 & 40.7 & 44.4 & 37.9 & 47.2 \\
\hline Peach & 16.1 & 24 & 18.7 & 18.1 & 20.1 & 18.4 & 17.4 & 21.1 \\
\hline \multicolumn{9}{|l|}{ Grains } \\
\hline Cooked & & & & & 35 & 16 & 31.9 & 19.1 \\
\hline Wheat & 46.9 & 23.1 & 16.9 & 15 & & & & \\
\hline Bread & 488.4 & 6.7 & 444.1 & 367 & 247.6 & 405.6 & 466.3 & 186.9 \\
\hline Rice & 249.9 & 198.5 & 276.1 & 201.8 & 224.2 & 239 & 263 & 200.3 \\
\hline Macaroni & 49.4 & 30.9 & 39.9 & 30.2 & 40.2 & 35.1 & 44.7 & 30.6 \\
\hline Oatmeal & 3.6 & 0.5 & 1.6 & 0.3 & 2.1 & 1 & 2.6 & 0.4 \\
\hline \multicolumn{9}{|l|}{ Fat and sweets } \\
\hline Chocolate & 28.8 & 26.2 & 21.1 & 28.3 & 27.5 & 24.7 & 25 & 27.3 \\
\hline Jams & 4.6 & 6.7 & 7.9 & 4.3 & 5.7 & 6.1 & 6.3 & 5.5 \\
\hline Sugars & 58.4 & 141.9 & 59.3 & 36.1 & 100.2 & 47.7 & 58.9 & 89 \\
\hline Olive oil & 25.6 & 25 & 107.7 & 28.7 & 25.3 & 68.2 & 66.7 & 26.9 \\
\hline Ghee & 5.6 & 2 & 3.6 & 2.1 & 3.8 & 2.9 & 4.6 & 2.1 \\
\hline Peanut butter & 2.8 & 2.2 & 4.1 & 6 & 2.5 & 5.1 & 3.5 & 4.1 \\
\hline Spreading butter & 1.8 & 4.4 & 2.9 & 6.4 & 3.1 & 4.7 & 2.4 & 5.4 \\
\hline \multicolumn{9}{|c|}{ Drinks and beverages } \\
\hline Coffee & 195.9 & 131.6 & 186.5 & 88 & 163.8 & 137.3 & 191.2 & 109.8 \\
\hline Tea & 400.5 & 380.7 & 425.7 & 411 & 390.6 & 418.4 & 413.1 & 395.9 \\
\hline
\end{tabular}


Am. J. Agri. \& Biol. Sci., 6 (3): 339-347, 2011

Table 4: Continue

\begin{tabular}{lllllllll}
\hline Carbonated & & & & & & & & \\
Beverages & 154.8 & 134.5 & 293.3 & 181.6 & 144.7 & 237.5 & 224.1 & 158.1 \\
Apple juice & 50.3 & 33 & 39.7 & 158 & 41.7 & 98.9 & 45 & 95.5 \\
Lemon juice & 41.2 & 33.5 & 38.9 & 32.9 & 37.4 & 35.9 & 40.1 & 33.2 \\
Orange juice & 116.3 & 64.6 & 119.6 & 68.7 & 90.5 & 94.2 & 118 & 66.7 \\
\hline
\end{tabular}

Table 5: Comparison of the average food consumption patterns (g/person/day) in Jordan and other countries

\begin{tabular}{|c|c|c|c|c|c|}
\hline Food group & $\mathrm{UK}^{1}$ & Egypt $^{2}$ & Lebanon $^{3}$ & Jordan* Amman & Al-Balqa \\
\hline Meat and poultry & 150 & 37.0 & 91.7 & 119.0 & 132.0 \\
\hline Fish & 27 & 19.9 & 19.6 & 14.2 & 13.8 \\
\hline Eggs & 23 & 17.0 & 12.1 & 31.9 & 36.1 \\
\hline Milk & 234 & 31.5 & 99.7 & 131.5 & 167.4 \\
\hline Dairy products & 29 & 77.1 & 143.4 & 169.8 & 188.6 \\
\hline Pulses, nuts and seeds & 34 & 56.1 & 39.5 & 16.5 & 16.1 \\
\hline Cereal and cereal-based products & 235 & 459.0 & 324.5 & 549.1 & 696.7 \\
\hline Potatoes & 126 & 55.6 & 63.5 & 91.4 & 105.1 \\
\hline Vegetables & 102 & 220.4 & 146.5 & 395.9 & 405.2 \\
\hline Fruits & 73 & 18.2 & 220.5 & 277.0 & 252.0 \\
\hline Added fats and oils & 19 & 24.1 & 20.4 & 34.7 & 80.9 \\
\hline Sugar & 18 & 73.5 & 33.9 & 100.2 & 47.7 \\
\hline
\end{tabular}

The present study showed that the mean consumption of fresh fruits and vegetables exceed the WHO/FAO minimum recommended value of $400 \mathrm{~g}$ daily (WHO, 2003). This could be due to the availability and accessibility of these products on the Jordanian market, their high national production and their relatively low cost, in addition to them being important ingredients of the traditional diet. On the other hand, The estimated average daily food intake in this study of many food items in both governorates were higher than those reported by the Jordanian food balance sheet, except the daily intake of sugars, meat and chick peas (DOS, 2008). Food balance sheet indicate that during 2003 the daily consumption per capita from cereals, sugars, oils, vegetables, fruits, meat, milk and milk products, eggs, fish and potatoes were $408.2 \mathrm{~g}, 107.4,63.3,238.6$, $211.6,107.1,143,16.4,8.2$ and 68.2 , respectively.

Chicken was most frequent consumed from meat group by males and females from both governorates. This could be due to the high price of beef and sheep meat compared to chicken, in addition to that Jordan does not considered as a fish producer so, it depends on the imported fish, which imply that fish would have a high price similar to that of beef and sheep and sometimes higher. Regarding beans group, chick peas (hummus) has the highest percent of consumption in males from both Amman and Al-Balq'a compared to females. This could be explained by high percentage of employee from males than females in both Amman and Al-Balq'a governorates (Table 1), which leads to an increase in the exposure to fast food because there is no enough time for cooking and thus increasing the demand for meals that can be prepared fast (Mdanat $e t$ al., 2008) and hummus is one of these meals. In grain group, bread and rice in general has the highest consumption percent in both males and females from both governorates with bread slightly higher than rice. This is simply because bread is considered the staple food in Jordan and therefore has a high consumption value. Rice from the other hand considered a main constituent in any meal and therefore considered a popular grain and forms the basis of healthy diet in Jordan (El-Qudah et al., 2008).

Consumption of fat and sweets were varying between the two governorates and between males and females. Sugars, has the highest percent of consumption, in males from Amman and females from Al-Balq'a, but females from Amman consumes chocolate more than other fat and sweets while males from Al-Balq'a consume olive oil more than other items. This can be referred to the difference in the lifestyle patterns between the two governorates and to the individual differences between males and females. According to the data collected tea the most popular drink in Jordan. It has the highest consumption values in males and females from both Amman and Al-Balq'a governorates. These findings could be related to the cold climate in these two governorates in that hot tea could warms the body up during the winter, also it can be related to the traditional habit in Jordan that emphasize on drinking tea after each meal.

A comparison between food consumption patterns in the adult population of Amman and Al-Balq'a governorates and those reported in other countries is presented in Table 5. Although the survey methodologies with which the consumption data were collected are variable between countries, food consumption trends could be identified (Gregory 1990; 
Saleh et al., 1998; Nasreddine et al., 2005). The dietary pattern in Jordan tends to differ from that of Egypt and Lebanon, other countries of the Middle East, by higher intakes of meat and poultry, eggs, milk, dairy products, cereals and cereal based products, potatoes vegetables and fruits, but the consumption of fish, pulses, nuts and seeds is lower than these countries. The consumption of eggs, vegetables and fruits in the present study were higher than in UK but the consumption of milk and potatoes were lower. Data suggest that caloric intake is increasing among all ethnicities, age and socioeconomic groups and diets contain more energydense, nutrient-poor foods (Troiano et al., 2000). Evidence also suggests that consumption of foods from fast-food restaurants, which typically serve foods high in total and saturated fat, has doubled during the past 30 years (French et al., 2001). Consumption of unhealthy foods may be replacing that of Fruits and Vegetables $(\mathrm{FV})$, which are known to provide essential vitamins, minerals and other nutrients (Troiano et al., 2000). Even though high levels of whole grain consumption have been linked to reduce rates of CVD and colon cancer, most adults do not consume enough of these foods (Popkin et al., 2005). In addition population studies indicate that individuals who regularly consume nuts especially almond have reduced risk for cardiovascular diseases and diabetes (Choudhary et al., 2009). Also, evidence regarding the readiness to change dietary habits among adults indicates that most adults are either not aware or not prepared to change their current dietary habits thus adding a layer of difficulty in trying to promote healthful eating habits (Baranowski $e t$ al., 1999). Given the strong link between diet and disease (Fung et al., 2001; Jahangeer et al., 2010; Shahwan-Akl, 2010), it is important to evaluate and address dietary behaviors and readiness for change at a young age for effective prevention of CVD and related co-morbidities.

\section{CONCLUSION}

The present study allowed the identification and quantification of the average daily intake of foods in the adult population in Amman and Al-Balq'a by means of an individual dietary survey. It is concluded from this study that the prevalence of overweight and obesity among males and females is high. There are significant differences between men and women regarding food consumption pattern. The data could be further used in nutritional assessment studies and may form the basis of future research into the associations between nutrients and the distribution of disease in the population. This study had, however, the following limitations: The study subjects may have under- or over reported their dietary intake36; the seasons during which the survey took place (spring/summer) could lead to overestimation of intake of certain food items such as fruits and vegetables.

\section{ACKNOWLEDGMENT}

Financial support from Deanship of scientific research, Al-Balqa Applied University is gratefully acknowledged and the persons who participated in the study are gratefully thanked.

\section{REFERENCES}

Ahmad, M.N., S.K.Tukan and H.R.Takruri, 2006. Obesity and overweight in young adult females of northern badia of Jordan. Mal. J. Nut., 12: 157166. http//nutriweb.org.my/publications/mjn00122/mjn12n2-art3.php

Ahmadi, E., A.R. Tehrani and A. Ahmadi, 2010. Prevalence of obesity, overweight and underweight among elementary school children in Southern Iran, 2009. Am. J. Applied Sci., 7: 1439-1442. DOI: 103844/ajassp.2010.1439.1442

Ajlouni, K., H. Jaddou and A.Batieha, 1998a. Obesity in Jordan. Int. J. Obes. Relat. Metab. Disord., 22: 624-628. DOI: $10.1038 \% 2$ Fsj.ijo.0800637

Ajlouni, K., H. Jaddou and A.Batieh, 1998b. Diabetes and impaired glucose tolerance in Jordan: Prevalence and associated risk factors. J. Int. Med., 244: $\quad 317-323$. DOI: $\quad 10.1046 \% 2 \mathrm{Fj} .1365-$ 2796.1998.00369.x

Al-Abad, F. A. and L.S. Al-Sowielem, 1998. Prevalence of obesity. Saudi Med. J., 19: 608-613. http://www.smj.org.sa/Contents-Next.asp

Al-Isa, A.N., 1995. Prevalence of obesity among adult Kuwaitis: A cross-sectional study. Int. J. Obesity, 19: 431-433. PMID: 7550529

Al-Nuaim, A.R., K. Al-Rubeaan, Y. Al-Mazrou, N. AlDaghari and T. Khoja, 1996. High prevalence of overweight and obesity in Saudi Arabia. Int. J. Obes. Relat. Metab. Disord., 20: 547-552. PMID: 8782731

Baranowski, T., K.W. Cullen and J.Baranowski, 1999. Psychosocial correlates of dietary intake: Advancing dietary intervention. Annual Rev. Nutr., $\quad 19$ : $\quad 17-40 . \quad$ DOI: 10.1146\%2Fannurev.nutr.19.1.17

CDC, 2006. Assessing risk factors for chronic diseaseJordan 2004. Morb. Mort. Week Rep., 55: 653655. http://www.cdc.gov/search.do 
DOS, 2009. Jordan Population and Family Health Survey 2010. Calverton, Maryland, USA: Department of Statistics and ORC Macro. http://www.dos.gov.jo/sdb-pop/sdb-pop-e/pop2009.pdf

DOS, 2008. Food Balance Sheet 2005-2007. Department of Statistics Jordan. http://www.dos.gov.jo/agr/agr-a/aver-2002 2007/aver\%202005-2007.pdf

El-Hazmi, M. A. and A.S.Warsy, 2000. Prevalence of overweight and obesity in diabetic and nondiabetic Saudis. Eastern Mediterranean Health J., 6:

276-282.

http://www.emro.who.int/publications/emhj/0602/ 08.htm

El-Qudah, J.M., B.F. Dababneh, A.A. AL-Bakheit, M.M. EL-Qudah, A. Al-Rawasdeh and M. Khataibeh et al., 2008. Nutrient contents per serving of twelve varieties of cooked rice marketed in Jordan. Am. J. Agric. Biol. Sci., 3: 617-622. DOI: 10.3844/ajabssp.2008.617.622

Epstein, F. H. and M. Higgins, 1992. Epidemiology of Obesity. In: Obesity, Bjorntorp, P. and B.N. Brodoff (Eds.). Lippincott Co., Philadelphia, pp: 230-342. ISBN: 0397509995

Fang, C. and H. Lee, 2009. Food-related lifestyle segments in Taiwan: Application of the foodrelated lifestyle instrument. Am. J. Applied Sci., 6: 2036-2042. DOI: 10.3844/ajassp.2009.2036.2042

French, S.A., M. Story, D. Neumark-Sztainer, J.A. Fulkerson and P. Hannan, 2001. Fast food restaurant use among adolescents: Associations with nutrient intake, food choices and behavioral and psychosocial variables. Int. J. Obes. Relat. Metab. Disord., 25: 1823-1833. DOI: 10.1038\%2Fsj.ijo.0801820

Fung, T.T., E.B. Rimm, D. Spiegelman, N. Rifai and G.H. Tofler et al., 2001. Association between dietary patterns and plasma biomarkers of obesity and Cardiovascular Disease Risk. Am. J. Clin. Nut., 73: 61-67. PMID: 11124, http://www.ajcn.org/content/73/1/61.short?rss = 1 andssource $=\mathrm{mfc}$

Choudhary, P., S. Kothari and V. Sharma, 2009. Almond consumption decreases fasting and post prandial blood glucose level in female type 2 diabetes subject. Am. J. Infect. Dis., 5: 109-111. DOI: 10.3844/ajidsp.2009.109.111

Gregory, J., 1990. The Dietary and Nutritional Survey of British Adults: A Survey of the Dietary Behavior, Nutritional Status and Blood Pressure of Adults Aged 16 to 64 Living in Great Britain. 1st Edn., HMSO, London, ISBN: 0116913002, pp: 392.
Gurney, M. and J. Gorstein, 1988. The global prevalence of obesity: An initial overview of available data. World Health Stat Q., 41: 251-254. PMID: 3232412

Jaddou, H., A. Batieha and K. Ajlouni, 1996. Prevalence and associated factors of hypertension results from a three community based survey. Jordan. J. Hum. Hypertens. 10: 815-21. http://www.nature.com/jhh/archive/index.html

Jahangeer, C., M.H. Khan, N.M. Khan and S. Jahangeer, 2010. The effect of risk factors on cardiovascular vascular diseases in Mauritius. Am. Med. J., 1: 4650. DOI: 10.3844/amjsp.2010.46.50

Jia, W. P., K.S. Xiang, L.L.J. Chen and Y.M. Wu, 2002. Epidemiological study on obesity and its comorbidities in urban Chinese older than 20 years of age in Shanghai, China. Obesity Rev., 3: 157165. DOI: 10.1046\%2Fj.1467-789X.2002.00071.x

Kroes R., D. Muller, J. Lambe, M.R. Lowik and J. Van Klaveren et al., 2002. Assessment of intake from the diet. Food Chem. Toxicol., 40: 327-385. DOI: 10.1016\%2FS0278-6915\%2801\%2900113-2

Manson, J.E., W.C. Willett, M.J. Stampfer, G.A. Colditz and D.J. Hunter et al., 1995. Body weight and mortality among women. NewEng. J. Med., 333: 677-685. DOI: 10.1056\%2FNEJM199509143331101

Mdanat, H.N., K.P. Troutman and B. Al- Madi, 2008. The Nutrition transition in Jordan: The political, economic and food consumption contexts. Promotion Educ., 15: 6-10. http://www.library.nhs.uk/booksandjournals/details .aspx

Molarius, A., J.C. Seidell, S. Sans, J. Tuomilehto and K. Kuulasmaa, 2000. Educational level, relative body weight and changes in their association over 10 years: An international perspective from the WHO MONICA Project. Am. J. Public Health, 90: 1260-1268. DOI: 10.2105\%2FAJPH.90.8.1260

Musaiger, A.O. and S.S. Miladi, 1996. Diet related noncommunicable diseases in the Arab Countries of the Gulf. FAO/RNE, Cairo. http://www4.fao.org/cgi-bin/faobib.exe

Musaiger, A.O., A.H.A. Al-Awadi and M.A. AlMannai, 2000. Lifestyle and social factors associated with obesity among the bahraini adult population. Ecol. Food Nutr., 39: 121-133. DOI: $10.1080 \% 2 \mathrm{~F} 03670244.2000 .9991610$

Nasreddine, L., N. Hwalla, A. Sibai, M. Hamze and D. Parent-Massin, 2005. Food consumption patterns in an adult urban population in Beirut. Lebanon. Public Health Nutr.. 9: 194-203. http://journals.cambridge.org/action/displayAbstra ct?fromPage $=$ onlineandaid = 584760andfulltextType $=$ RAandfileId $=$ S1368980006000383 
Pellett, P.L., 1970. Food Composition Tables for Use in the Middle East. 2nd Edn., American University of Beirut, Beirut, Lebanon, pp: 116. http://www.amazon.com/Food-compositionTables-Middle-East/dp/B0006C5GB0

Popkin, B.M., K. Duffey and P. Gordon-Larsen, 2005. Environmental influences on food choice, physical activity and energy balance. Physiol. Behav., 86: 603-613. DOI: 10.1016\%2Fj.physbeh.2005.08.051

Shahwan-Akl, L., 2010. Cardiovascular disease risk factors among adult Australian-Lebanese in Melbourne. Int. J. Res. Nurs., 1: 1-7. DOI: 10.3844/ijrnsp.2010.1.7

Saleh, Z.A., H. Brunn, R. Paetzold and L. Hussein, 1998. Nutrients and chemicalresidues in an Egyptian total mixed diet. Food Chem., 63: 535-541. DOI: $10.1016 \% 2 F S 0308-8146 \% 2898 \% 2900005-3$

Takruri, H.R., 2003. Obesity in Jordan. Arab J. Food Nutr., 4:

$68-$ 84.http://dx.doi.org/10.1109\%2FICECS.2003.130 1985

Troiano, R.P., R.R. Briefel, M.D. Carroll and K. Bialostosky, K 2000. Energy and fat intakes of children and adolescents in the United States: Data from the National Health and Nutrition Examination Surveys. Am. J. Clin. Nutr., 72: 1343S-1353S.

http://www.ajcn.org/content/72/5/1343S.abstract
USDA, 2007. National Nutrient Database for Standard Reference. http://www.nal.usda.gov/fnic/foodcomp/search

WHO, 1998. World Health Report, Life in the 21st century: A vision for all. Geneva, 132. http://www.who.int/whr/1998/en/whr98-en.pdf

WHO, 1999. Definition, Diagnosis and Classification of Diabetes Mellitus and Its Complications. Part 1: Diagnosis and Classification of Diabetes Mellitus. Provisional Report of a WHO Consultation. Geneva, 1999. http://whqlibdoc.who.int/hq/1999/who-ncd-ncs99.2.pdfWorld Health Organization

WHO, 2003. Diet, Nutrition and the Prevention of Chronic Disease. Report of a Joint WHO/FAO Expert Consultation, Geneva. http://whqlibdoc.who.int/trs/who_trs_916.pdf 